tinguished for arranging its exhibits in attractive form and for publications designed to appeal to all with an interest in natural history. The latest publication, "Handbook to the Australian Museum", replaces the former "Guide" and has been designed to help make visits to the Museum of increased interest by providing information not only about the exhibits themselves but also of the theme that links them all together. Approximately 250,000 people visit the Museum each year.

The report of the Trustees of the Australian Museum for the year ended June 30, 1957 (pp. 23. Sydney : The Australian Museum, 1958), includes a valuable summary of the growth and development of this progressive institution. The main purpose of this statement is to indicate that for a period of no less than forty-seven years no major building developments have taken place, and this in spite of many applications to the authorities for increased accommodation. Plans and designs for new displays have been prepared for the aboriginal, bird, fish, invertebrate, insect, mineral, mammal and fossil galleries. Special quarterly exhibits help to produce a lively atmosphere, and popular lectures on scientific subjects connected with the museum objects are well attended.

\section{Library Resources in the West Midlands}

THE West Midlands Group of the Reference and Special Libraries Section of the Library Association has compiled a "Guide to Library Resources in the West Midlands" (pp. viii +49 . London : Library Association, 1958. 15s.). Edited by B. G. Staples, it indicates the character, coverage and availability of 178 libraries in Herefordshire, Shropshire, Staffordshire, Warwickshire and Worcestershire. The staff, book-stock and number of periodicals, but not the titles, are given and only to a limited extent does it supply a picture of the resources of the region. There are two indexes: one, topographical, showing the different types of library in each locality; while the general index gives a key to particular subject fields and named collections, as well as indicating where microcard and microfilm readers and certain classes of material can be found. This well-produced pamphlet bears further witness to the preparatory work which this and similar groups are carrying out in different parts of Britain and on which an adequate regional library system may perhaps ultimately be based.

\section{Health Physics}

A NEw journal is a mixed blessing. The hopeful scribe sees in it another vehicle for his works, while the harassed executive sighs at the thought of more to read. Nevertheless, no one can grudge a new discipline its own organ. Health physics is such a new discipline; a Health Physics Society has recently been formed in the United States and has now published the first issue of its journal, Health Physics (1, No. 1, June 1958. Pp. 95. Subscription: 17 dollars; $120 s$. per annum. New York and London : Pergamon Press, 1958). In the foreword by K. Z. Morgan (editor-in-chief) health physics is defined "as a study and practice dealing with any and all factors relating to damage from ionizing radiation and the prevention of such damage". With the rapid promotion of nuclear energy and the increasing utilization of its by-products, there can be no doubt that the fantastic growth of this new corps of specialists from a handful of dedicated enthusiasts to a substantial army will be continued. They will welcome this journal devoted to "(1) Research, (2) Engineering, (3) Applied, and (4) General"-which is a fairly broad programme-and the first number, of June, has plenty of category (4).

\section{"Atom 1959"}

UNDER the title "Atom 1958" (pp. 24. London: H.M. Stationery Office, 1958), the Atomic Energy Authority has issued for general reading a summary, with illustrations, of the Authority's fourth annual report (see also p. 615 of this issue of Nature). The pamphlet describes in non-technical terms the progress of the power programme, the possibilities for the next two decades, including the prospects for a fusion reactor, and the relations of the Authority with industry and with other countries. Besides some notes on health and safety and the supply of fuel for reactors, it includes an outline of the Authority's organization and lists of its establishments and publications. It is a well-planned contribution to public relations which should help to remove some popular misunderstandings and dispel the dangerous sense of mystery with which those relations are sometimes cloaked.

\section{Czechoslovak-Hungarian Polarographic Conference}

THE Czechoslovak-Hungarian Polarographic Conference in Prague was held during July 13-24 following the similar meeting held in 1955 at the Hungarian Chemical University in Veszprém. The Conference was arranged by the Polarographic Institute of the Czechoslovak Academy of Sciences under the auspices of its Chemical Section. Prof. J. Heyrovskv́ presided. The Hungarian delegation consisted of nineteen scientists and was led by Prof. J. Proszt (Budapest Technical University), Prof. K. Polinszky (dean, Veszprém Chemical University) and Dr. V. Cieleszky (chairman, Polarographic Section, Hungarian Chemical Society). Besides these, there were thirty-five visitors from Budapest and several polarographic experts from other countries, including Prof. G. Semerano (Padua); Dr. Z. Zagórski (Poznań); W. Stolle (German Academy, Berlin), who brought a gift of a newly constructed pen-recording polarograph; L. Lukashev (Bulgaria); Prof. B. P. Bruns (Moscow); and Dr. R. J. Magee (The Queen's University, Belfast). Sixty-three papers were presented at the Conference in two sections: $A$, inorganic-analytical; and $B$, organic and biochemical. After the meetings in Prague the delegates went to Bratislava and were shown around research establishments and chemical works in Czechoslovakia, as well as the Tatra Mountains. The majority of the papers were of high standard and some indicated new directions in polarography. They will be published chiefly in "Collection of Czechoslovak Chemical Communications". Those who are interested in the abstracts of the Communications should apply to Prof. J. Heyrovský, Polarographic Institute of the Czechoslovak Academy of Sciences, Vlašská 9, Prague 1, Czechoslovakia.

\section{A Submarine Volcano}

As reported by Y. Y. Gakkel (Priroda, 4, 87; 1958), the members of the polar drifting station in November 1955 discovered a submarine volcano situated at $88^{\circ} 16^{\prime} \mathrm{N}$., $65^{\circ} 36^{\prime} \mathrm{W}$. on the Lomonosov submarine ridge near the North Pole. The nature of the ice-quakes, noises and hydrogen sulphide emerging from a crack in the ic $\theta$-all these phenomena have 